\title{
Familial cavernous malformations in a large French kindred: mapping of the gene to the CCM1 locus on chromosome $7 \mathrm{q}$
}

L Notelet, F Chapon, S Khoury, K Vahedi, J P Chodkiewicz, P Courtheoux, M T Iba-Zizen, E A Cabanis, B Lechevalier, E Tournier-Lasserve, J P Houtteville

\begin{abstract}
Objectives-To characterise clinically a large French family affected with cerebral cavernomas and to check for linkage of this condition to chromosome 7 .

Methods-A family, originating from Normandy and in which five members had undergone surgery for cavernomas, was extended. All members older than 18 were studied clinically and by neuroimaging. Genetic linkage analysis was conducted using 11 polymorphic microsatellite markers located between D7S502 and D7S479.
\end{abstract}

Laboratoire de
Neuropathologie CHRU de Caen,

France

L Notelet

F Chapon

B Lechevalier

Inserm U 25, Faculté de Médecine de

Necker, Paris, France

L Notelet

K Vahedi

E Tournier-Lasserve

Service de

Neurochirurgie,

CHRU de Caen,

France

S Khoury

JP Houtteville

Service de

Neurochirurgie,

Centre hospitalier

Sainte Anne, Paris,

France

JP Chodkiewicz

Service d'imagerie, CHRU de Caen,

France

P Courtheoux

Service d'imagerie par résonance magnétique, Höpital des

Quinze-vingts, Paris, France

MT Iba-Zizen

EA Cabanis

Correspondence to: Dr E Tournier-Lasserve, INSERM U25, Faculté de médecine Necker, 156 rue de Vaugirard, Paris, 75015,

France.

Received 16 May 1996 and in revised form 6 January 1997

Accepted 22 January 1997
Results-The family included three generations. Among the 25 members investigated, 11 had an abnormal cerebral MRI, eight of them being symptomatic, and 12 were asymptomatic with a normal MRI. The status of the two remaining members could not be established on the basis of clinical and MRI data. The family reported shares some striking features with other previously linked families-namely, a high clinical penetrance and the presence of multiple lesions within most of the affected members. A lod score of 4.04 was obtained with marker D7S657 with no recombinant. Significant lod scores were also obtained with D7S524 (Zmax=3.32 at $\theta=0.00)$ and D7S630 (Zmax $=3.44$ at $\theta=0.00)$. These results establish linkage of the condition found in this family to chromosome 7. Haplotype analysis strongly suggests that the gene is telomeric to D7S802 and centromeric to D7S479.

Conclusions-These data confirm linkage of cerebral cavernous malformations to chromosome 7 in a non-Hispanic family.

(F Neurol Neurosurg Psychiatry 1997;63:40-45)

Keywords: vascular malformation; cavernoma; brain; genetics

Intracranial cavernomas (or cavernous vascular malformations or cavernous haemangiomas) histological appearance is characteristic, with the juxtaposition of vascular capillary cavities without intervening brain parenchyma. ${ }^{12}$ Vascular walls can be very thin, with a "lacework" appearance, or thicker, due to recurrent parietal thromboses. ${ }^{1-3}$

According to postmortem studies, the prevalence of cavernomas has been estimated as are so far considered to be hamartomas. ${ }^{1}$ Their
$0.5 \%$ in the general population. ${ }^{4-6}$ Clinical onset usually occurs between the third and fourth decades of life, ${ }^{278}$ but the first symptoms may appear at all ages. ${ }^{9-11}$ Symptomatic cavernomas are rarely life threatening but, depending on their location, may cause severe clinical disability. ${ }^{8}{ }^{12}$ Clinical presentation includes epileptic seizures $(30 \%$ to $50 \%$ of patients), focal neurological deficits (10 to $35 \%)$, headaches $(20 \%$ to $30 \%)$, and recurrent haemorrhages, more often occult. ${ }^{25613-16}$

Diagnosis is usually made on cerebral MRI, which is more sensitive than CT and shows, in typical cases, a heterogeneous core signal surrounded by a hypointense ring on $\mathrm{T} 2$ weighted images. ${ }^{17} 18$

The frequency of familial cerebral cavernous malformations has been estimated by some authors to be as high as $50 \%$ of clinical cases. ${ }^{19} 20$ However, this frequency may have been overestimated due to collection biases, particularly in Hispanic-American families. ${ }^{18-22}$ The pattern of inheritance is in most cases autosomal dominant with incomplete clinical penetrance. Cavernomas can be detected on cerebral MRI in clinically asymptomatic people who have transmitted the disease to their offspring. ${ }^{19}$ Patients with cerebral cavernous malformations often have multiple localisations (up to $75 \%$ of patients), and these seem to be associated with earlier age of onset. ${ }^{2123-25}$

Whereas an operative decision is widely accepted when cavernomas are symptomatic and easily accessible, it is still controversial when they are deep seated or located in functional brain areas. ${ }^{5714182627}$ The lack of knowledge about natural history of cerebral cavernomas makes therapeutical decisions often difficult.

Recently, Dubovsky et al mapped a gene responsible for cerebral cavernous malformations (CCM gene) in a large hispanic family to chromosome $7 \mathrm{q} 11-\mathrm{q} 22$, in a $33 \mathrm{cM}$ interval bracketed by markers D7S502 and D7S479. ${ }^{28}$ This genetic mapping has been confirmed in 10 additional families, seven of them being Hispanic-American and the other three white. ${ }^{29-33}$ The analysis of two of these families allowed Günel et al to reduce the size of the mapping interval to $7 \mathrm{cM}$, the most likely interval being bracketed by ELN (the elastin gene) and D7S802. ${ }^{29}$ Genetic mapping of the CCM gene centromeric to D7S802 was supported by one crossover event which occurred in an affected member. By contrast with these results, Johnson et al analysed addi- 


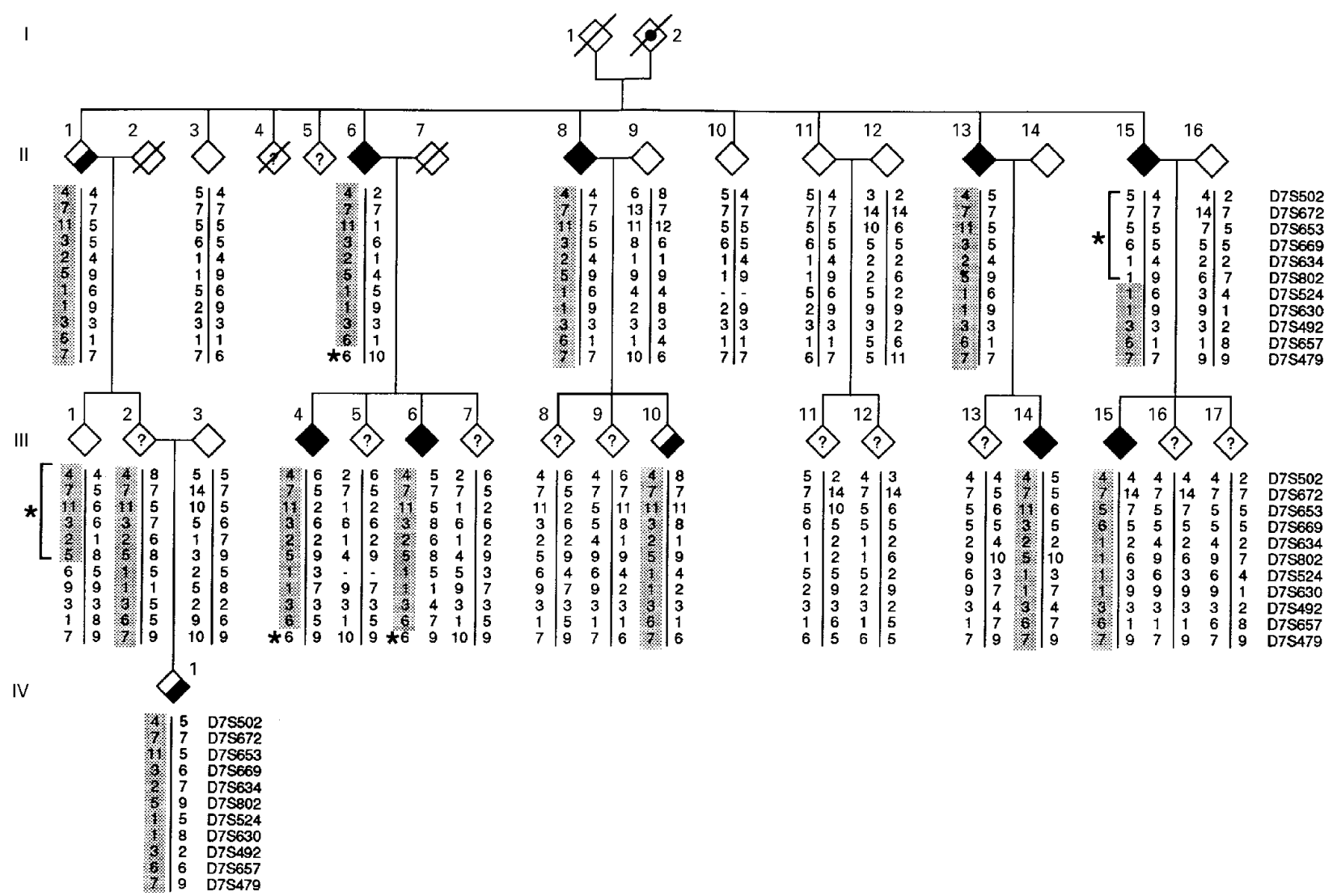

Figure 1 Pedigree and chromosome 7 haplotypes. The affected patients are represented by a filled symbol when they have neurological symptoms, by a filled circle when the symptoms are assumed on the basis of familial history, and by a half filled symbol when they have only an abnormal MRI. Open symbols represent unaffected subjects older than 45 years and question marks represent subjects younger than 45 years. The haplotypes obtained with D7S502, D7S672, D7S653, D7S669, D7S634, D7S802, D7S524, D7S630, D7S492, D7S657, and D7S479 are indicated. Three crossover events were seen in two clinically affected members (II-15, II-6) and one clinically asymptomatic member having a normal MRI and aged 49 (III-1). Haplotypes strongly suggest that the gene is telomeric to D7S802 and centromeric to D7S479.

tional families in which several crossover events strongly suggest that the gene causing cavernomas in these families is telomeric to D7S802 and resides within a $4 \mathrm{cM}$ interval flanked by D7S2410 and D7S689. ${ }^{31}$ Recently Günel et al excluded linkage to $7 \mathrm{q}$ in two non-Hispanic families and established the genetic heterogeneity of this condition. ${ }^{33}$

Herein we report the results of a clinical, neuroimaging, and genetic linkage analysis conducted in a large family originating from France. Haplotype analysis strongly suggests

Table 1 Clinical and MRI features of affected patients

\begin{tabular}{|c|c|c|c|c|c|c|}
\hline Patients & $\begin{array}{l}\text { Clinical } \\
\text { symptoms }\end{array}$ & $\begin{array}{l}\text { Age of } \\
\text { onset }(y)\end{array}$ & $\begin{array}{l}\text { No of lesions } \\
\text { (MRI) }\end{array}$ & $\begin{array}{l}\text { Surgery } \\
\text { age }(y)\end{array}$ & Location & Histology \\
\hline II-1 & Healthy & - & $>1$ & - & - & - \\
\hline II-6 & $\begin{array}{l}\text { Seizures: } \\
\text { focal deficit }\end{array}$ & 18 & $>1$ & 57 & & $\begin{array}{l}\text { Cavernous } \\
\text { angioma }\end{array}$ \\
\hline II-8 & Focal deficit & 35 & $>1$ & - & - & - \\
\hline II-13 & Seizures & 18 & $>1$ & - & - & - \\
\hline II-15 & $\begin{array}{l}\text { Trigeminal } \\
\text { neuralgia }\end{array}$ & 47 & $>1$ & - & - & - \\
\hline \multirow[t]{2}{*}{ III-4 } & Seizures & 14 & $>1$ & 14 & $\begin{array}{l}\text { Parieto- } \\
\text { occipital }\end{array}$ & $\begin{array}{l}\text { Cavernous } \\
\text { angioma }\end{array}$ \\
\hline & Focal deficit & 18 & & 18 & Pons & $\begin{array}{l}\text { Complex vascular } \\
\text { malformation }\end{array}$ \\
\hline III-6 & Seizures & 20 & 1 & 20 and 32 & Temporal & $\begin{array}{l}\text { Cavernous } \\
\text { angioma }\end{array}$ \\
\hline III-10 & Healthy & - & 1 & - & - & - \\
\hline III-14 & Haemorrhage & 8 & 1 & 8 & Frontal & $\begin{array}{l}\text { Cavernous } \\
\text { angioma }\end{array}$ \\
\hline III-15 & Haemorrhage & 5 & $>1$ & 19 & Thalamic & $\begin{array}{l}\text { Complex vascular } \\
\text { malformation }\end{array}$ \\
\hline IV-3 & Headaches & Childhood & $>1$ & - & - & - \\
\hline
\end{tabular}

that the gene lies telomeric to D7S802, within an interval bracketed by D7S802 and D7S479.

\section{Materials and methods}

CLINICAL AND PATHOLOGICAL EVALUATION

The study protocol was approved by the Comité Consultatif pour la Protection des Personnes dans la Recherche Biomédicale at the Université de Médecine de Caen. The family reported herein originates from Normandy (western France) and includes three generations (fig 1). Five members (II-6, III-4, III-6, III-14, III-15) had undergone surgery for cavernomas before this study was started. In four of them the diagnosis of cavernous angiomas was confirmed by pathological analysis. In the other, there was insufficient material for precise characterisation of the lesion.

Based on family history, member I-2 was said to have been operated on in 1955 for a cerebellar haemorrhage due to a vascular malformation.

Twenty five members were then studied clinically and by neuroimaging; MRI was performed using $\mathrm{T} 1$ weighted and first and second echo T2 weighted sequences. Cavernomas were identified using previously established criteria. ${ }^{1819}$ For pathological study, all specimens were processed using glutaraldehyde or formalin fixative, embedded in paraffin, and stained with haematoxylin and eosin, Gomori trichrome, and elastin stain. 


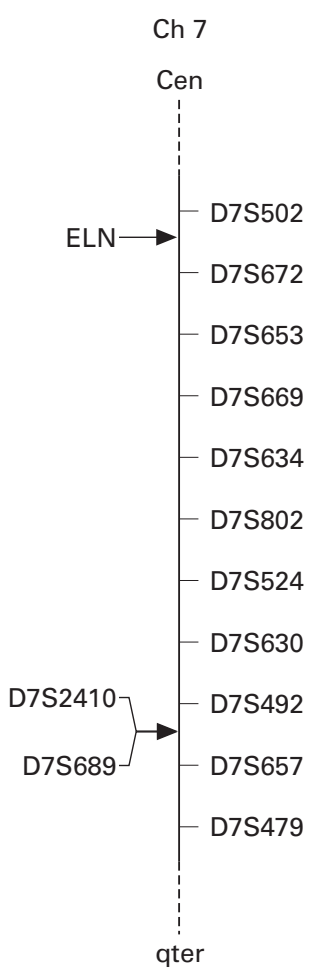

Figure 2 Genotypic regional map of chromosome 7. Critical markers used for linkage analysis are shown on the right side (genetic distances between these markers are indicated in the Genethon map (see Dib et $a l^{40}$ ). On the left are shown the respective positions of the elastin gene (ELN) and D7S2410 and D7S689.

\section{GENOTYPING AND LINKAGE ANALYSIS}

Markers

Eleven polymorphic microsatellite markers located between D7S502 and D7S479 were chosen from the Genethon linkage map, and CHLC linkage map on the basis of their informativity (fig 2): D7S502, D7S672, D7S653, D7S669, D7S634, D7S802, D7S524, D7S630, D7S492, D7S657, and D7S479. ${ }^{35}$ All oligonucleotides sequences are available through the Genome Data Base (John Hopkins University, Baltimore, USA).

LINKAGE ANALYSIS

DNA was extracted from peripheral blood of all consenting members. Based on previous data suggesting the incomplete clinical penetrance of this condition, MRI was used to establish the status of a given member for linkage analysis. Members with an abnormal MRI were considered as affected, whether or not they were clinically symptomatic. Asymptomatic subjects having a normal MRI were con-

Table 2 Pairwise linkage data

\begin{tabular}{lcccccccc}
\hline \multirow{7}{*}{ Locus } & 0.00 & 0.05 & 0.1 & 0.2 & 0.3 & 0.4 & \multirow{2}{*}{ Z max } & $\theta$ \\
\cline { 2 - 6 } & & & & & & \\
D7S502 & -3.82 & 0.33 & 0.68 & 0.75 & 0.51 & 0.19 & 0.78 & 0.16 \\
D7S669 & -4.44 & 1.01 & 1.15 & 1.02 & 0.66 & 0.23 & 1.16 & 0.11 \\
D7S634 & -4.30 & 1.22 & 1.33 & 1.13 & 0.70 & 0.23 & 1.33 & 0.10 \\
D7S802 & -3.95 & 1.60 & 1.70 & 1.47 & 0.98 & 0.36 & 1.70 & 0.10 \\
D7S524 & 3.32 & 3.02 & 2.70 & 2.01 & 1.25 & 0.45 & 3.32 & 0.00 \\
D7S630 & 3.44 & 3.14 & 2.82 & 2.13 & 1.35 & 0.49 & 3.44 & 0.00 \\
D7S657 & 4.04 & 3.69 & 3.33 & 2.53 & 1.64 & 0.64 & 4.04 & 0.00 \\
D7S479 & -4.33 & 0.24 & 0.46 & 0.48 & 0.32 & 0.12 & 0.51 & 0.15 \\
\hline
\end{tabular}

sidered as "healthy" when aged older than 45 . Asymptomatic subjects with a normal MRI and younger than 45 years, were considered as having an unknown status.

Twenty five family members were studied, including 16 potentially informative meiosis, and 10 of unknown status. In addition, blood samples were taken from four spouses to analyse their offspring. Polymorphic genomic sequences were amplified by polymerase chain reaction as previously described. ${ }^{36}$

Linkage analysis was performed using the 5.1 version of the Linkage program package ${ }^{37}$ using published allele frequencies from $\mathrm{CEPH}$ pedigrees. The most likely haplotypes were inferred for each person by minimising the number of crossover events in each sibship.

\section{Results}

CLINICAL AND NEUROIMAGING INVESTIGATIONS Among the 25 investigated members, 11 had an abnormal cerebral MRI highly suggestive of cavernomas (fig 3), eight of them being symptomatic. Five of these had undergone surgery. Table 1 shows the age of onset and clinical symptoms found in these patients. Twelve had a normal MRI and were totally asymptomatic. Four were older than 45 years, the oldest one, II-3, being 71 . Among the eight asymptomatic subjects younger than 45 , the youngest one was aged 18.

For subjects III-2 and III-17 it was not possible to be definitive. Member III-2, who has severe headaches had an abnormal MRI with a temporal cortical lesion presenting as an hypointensity on T2 weighted images including a punctate area of increased signal intensity. This image strongly suggested the diagnosis of either a cavernoma or a thrombosed angioma (fig 3E). This member has a son affected with two typical cavernoma lesions and was therefore considered as an obligate carrier. The MRI of subject III-17, aged 16 and totally asymptomatic, showed a right paraventricular lesion presenting as an hyposignal on $\mathrm{T} 1$ weighted images and an hypersignal on T2 weighted images without any change on a four year interval. This subject was considered as having an unknown status.

PATHOLOGICAL INVESTIGATIONS

Seven resected cerebral specimens from five patients (II-6, III-4, III-6, III-14, and III-15; and III- 4 and III- 6 both operated on twice) were available for neuropathological examination. Typical cavernoma lesions were found in patient II-6 (fig 4), and patients III-4, III-6, and III-14. In patient III-15, findings were consistent with a mixed vascular malformation including dilated vascular channels without intervening neural tissue as well as venous vessels.

One patient, II-15, presenting typical cavernomas on cerebral MRI, underwent dorsal surgery for a recurrent thoracic intercostal neuralgia. Interestingly, surgical investigation showed a vascular malformation in the laterospinal space at the T10 thoracic level strongly suggesting a venous angioma, confirmed by pathological examination. 

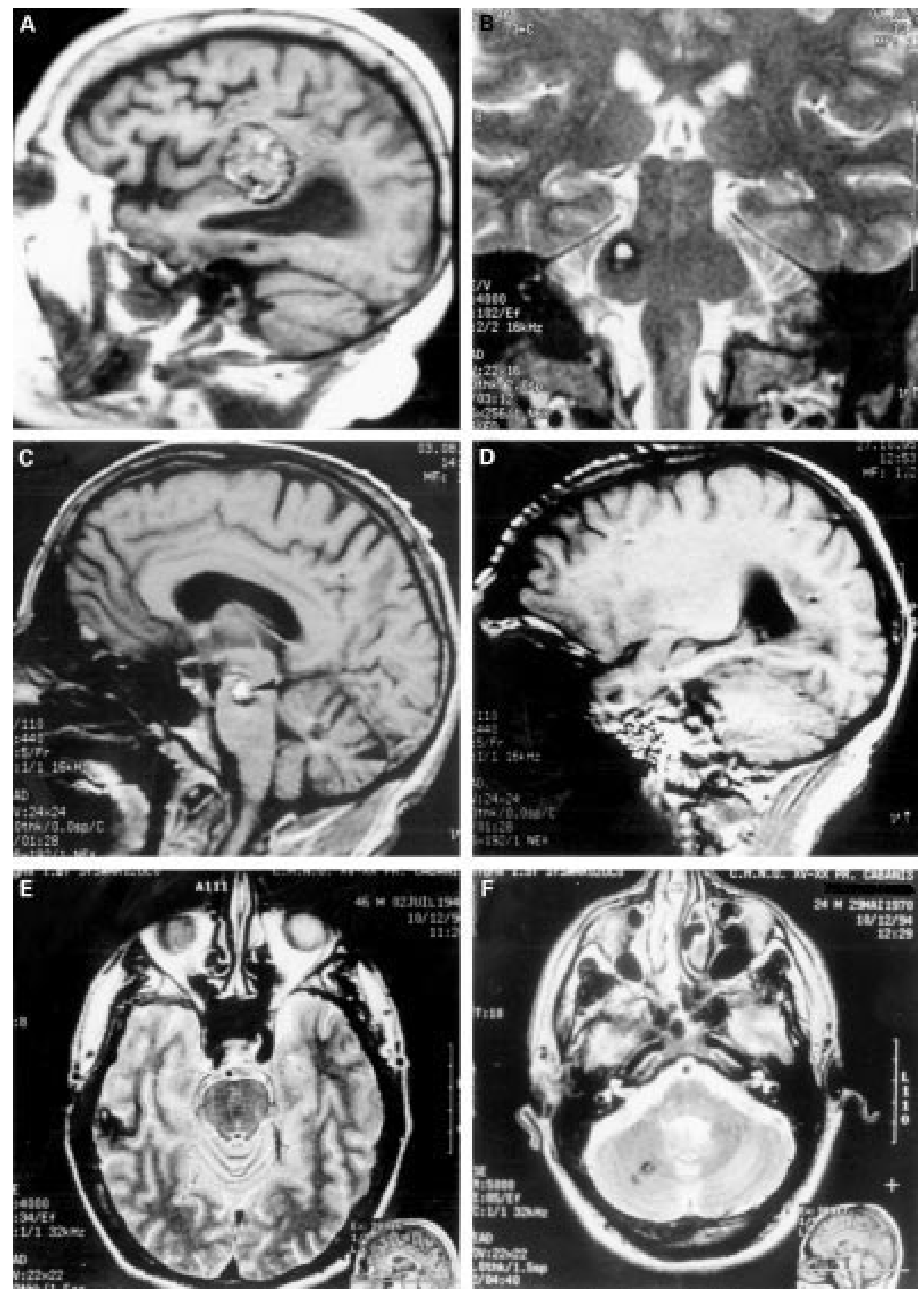

Figure 3 Typical features of cavernous angiomas on MRI from several affected members. (A) Patient II-6: sagittal T1 weighted image. Rolandic lesion with a reticulated core of mixed increased and decreased signal intensity surrounded by a rim of decreased signal. (B) Patient III-10: coronal T2 weighted section. Upper cerebellar pedoncle lesion. (C) Patient II-5: sagittal T1 weighted image. Pontine lesion. (D) Patient II-1: sagittal T1 weighted section. Multiple supratentorial

hypointense and hyperintense small lesions. (E) Patient III-2: axial T2 weighted section. Small hyperintense area inside a right temporal hypointense lesion. (F) Patient IV-1: axial T2 weighted section. Lesion in the right cerebellar hemisphere.

LINKAGE DATA

Table 2 shows the two point linkage data. Significant lod scores were obtained for markers D7S657 (LS $=4.04$ at $\theta=0.00)$ and D7S630 (LS $=3.44$ at $\theta=0.00$ ). No recombinant was found with these two markers. Positive lod scores were also obtained for several additional closely linked markers (table 2). These data establish linkage of the condition present in this family to chromosome 7 .
The analysis of inherited haplotypes shows three crossover events (fig 1) strongly suggesting that the CCM1 gene is flanked proximally by marker D7S802 and distally by marker D7S479. Two recombinants were found with D7S802 (III-1, II-15). One of them, III-1, is a 49 year old asymptomatic person with a normal MRI. The second one, II-15, is a clinically affected patient with multiple cavernoma lesions on cerebral MRI. This patient has three 


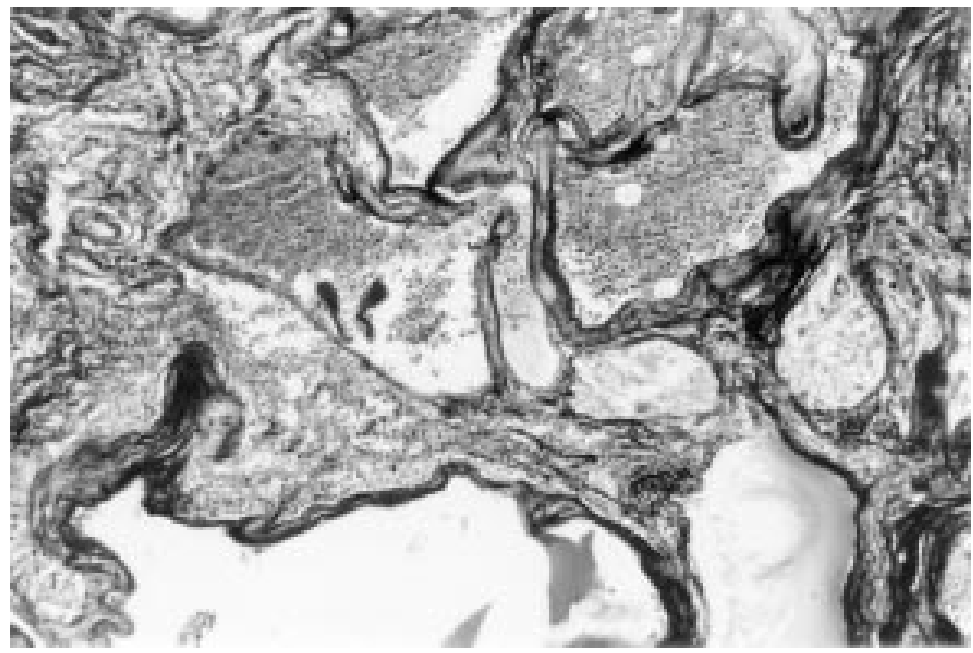

Figure 4 Patient II-6: histological appearance of lesion illustrated in fig 3A: juxtaposition of vascular cavities lined by a thin layer of endothelial cells and connective tisssue without intervening brain tissue. Modified Gomori trichrome stain. Originally $\times 32$.

children, among whom one, III-15, had multiple typical cavernoma lesions on cerebral MRI. One crossover event was seen with marker D7S479; it occured in an affected patient, II-6, showing a typical cavernoma lesion on resected cerebral specimen.

These data support the most likely placement of the CCM1 gene between D7S802 and D7S479.

\section{Discussion}

Recently Dubovsky et al mapped a gene on chromosome 7 causing familial cavernomas within a Hispanic-American family. ${ }^{28}$ This mapping was confirmed in seven other Hispanic-American families and three white families. ${ }^{29-33}$ We report herein a large French kindred affected with familial cerebral cavernomas in which we established linkage to chromosome $7 \mathrm{q}$.

It was first suggested on only a few families that cerebral cavernous malformations may be a genetically homogenous condition. Recently, Günel et al excluded linkage to $7 \mathrm{q}$ in two nonHispanic families with cerebral cavernous malformations. ${ }^{33}$ Clinical features of these families were similar to those found in families presenting linkage to $7 \mathrm{q}$.

Interestingly, in the family reported here, two patients presenting multiple lesions highly suggestive of cavernomas on cerebral MRI and carrying the affected haplotype, presented other vascular malformations. Patient II-15 had a spinal venous angioma and his daughter, III-15, had a mixed vascular malformation. Such associations have been reported in the literature, raising the question of the nosological link between these various vascular malformations. ${ }^{21} 39$ The availability of genetic markers which can identify, within a family with various vascular malformations, the members carrying the affected gene will in the very near future help to ascertain whether these various malformations are the result of the same genetic alteration.

Haplotype analysis in the French family strongly suggests that the CCM1 gene is most likely telomeric to D7S802 in agreement with the data of Johnson et al. ${ }^{31}$ Based on one crossover event in an affected patient belonging to an Italian-American family, Günel et al suggested that the most likely placement of the gene would be centromeric to D7S802. ${ }^{29}$ These apparent discrepancies could be explained in different ways, including, as suggested by the authors, the absence of linkage to chromosome 7 of the family. Another explanation could be that there is more than one CCM gene on 7q, which may have arisen by duplication. The analysis of additional families and particularly families of a large size is needed to reach a conclusion.

A founder effect has been found in HispanicAmerican families, as confirmed by the recent studies of Günel et al. ${ }^{31}{ }^{34}$ The comparison of the size of the "affected" alleles segregating in our family with those previously reported does not show any common allele either with the Hispanic-American or white families previously reported (data not shown). However, additional families are currently being analysed to search for a linkage disequilibrium within families of French ancestry.

The analysis of additional families will also help in positional cloning of the CCM1 gene which is ongoing in several teams and should provide a useful tool for direct genotypic diagnosis as well as a better understanding of this condition in the future.

We thank all members of this family for their participation. Help from Professors Rey, Philippon, Daumas-Duport, and Drs Mauvais and Lagnier was greatly appreciated. LN was supported by a fellowship from the Conseil Regional de Bane Normandie. This work was supported by INSERM and Ministère de l'Ensignement Supèrieur et de la Recherche (MESR).

1 Russel DS, Rubinstein LJ. Tumours and tumour-like lesions of maldevelopmental origin. Vascular hamartomas. Pathology of tumours of the nervous system. 5th ed. London: Edward Arnold, 1989:727-65.

2 Simard JM, Garcia-Bengochea F, Ballinger WE, et al. Cavernous angioma: a review of 126 collected and 12 new ernous angioma: a review of 126 collected
clinical cases. Neurosurgery 1986;18:162-72.

3 Lechevalier B: Etude neuropathologique des cavernomes. Neurochirurgie 1989;35:78-81.

4 Otten P, Pizzolato GP, Rilliet B, Berney J. A propos de 131 cas d'angiomes caverneux (cavernomes) du S.N.C., repérés par l'analyse rétrospective de 24535 autopsies. Neurochirurgie 1989;35:82-3.

5 Robinson JR, Awad IA, Little JR. Natural history of the cavernous angioma. $\mathcal{f}$ Neurosurg 1991;75:709-14.

6 Del Curling O, Kelly DL, Elster AD, Craven TE. An analysis of the natural history of the cavernous angiomas. $f \mathrm{Neu}$ rosurg 1991;75:702-8

7 Bertalanffy H, Kühn G, Scheremet R, Seeger W. Indications for surgery and prognosis in patients with cerebral cavern-

ous angiomas. Neurol Med Chir (Tokyo) 1992;32:659-66. Robinson JR, Awad IA, Magdinec M, Paranandi L. Factors predisposing to clinical disability in patients with cavernous

9 Mazza C, Scienza R, Beltramello A, Da Pian R. Cerebral Mazza C, Scienza R, Beltramello A, Da Pian R. Cerebral
cavernous malformations (cavernomas) in the pediatric cavernous malformations (cavernomas) in
age-group. Childs Nerv Syst 1991;7:139-46.

10 Scott RM, Barnes P, Kupsky W, Adelman LS. Cavernous angiomas of the central nervous system in children. $f \mathrm{Neu}$ rosurg 1992;76:38-46.

11 Malik S, Cohen BH, Robinson J, et al. Progressive vision loss. A rare manifestation of familial cavernous angiomas. Arch Neurol 1992;49:170-3.

12 Zimmerman RS, Spetzler RF, Lee KS, et al. Cavernous malformations of the brain stem. $\mathcal{F}$ Neurosurg 1991;75:32-9.

13 Voigt K, Yasargil MG. Cerebral cavernous haemangiomas or cavernomas. Incidence, pathology, localization, diagnosis, clinical features, and treatment. Review of the literature and report of an unusual case. Neurochirurgia 1976;19:59-68.

14 Requena I, Arias M, Lopez-Ibor L, et al. Cavernomas of the central nervous system: clinical and neuroimaging manifestations in 47 patients. F Neurol Neurosurg Psychiatry 1991;54:590-4

15 Aiba T, Tanaka R, Koike T, Kameyama S, Takeda N, Komata T. Natural history of cavernous malformations. $\mathcal{f}$ Neurosurg 1995;83:56-9. 
16 Houtteville JP. The surgery of cavernomas both supratentorial and infra-tentorial. Adv Tech Stand Neurosurg tentorial and inf

17 Rigamonti D, Drayer BP, Johnson PC, Hadley MN, Zabramski JM, Spetzler RF. The MRI appearance of cavernous malformations (angiomas). $f$ Neurosurg 1987; 67:518-24

18 Zabramski JM, Wascher TM, Spetzler RF, et al. The natural history of familial cavernous malformations: results of an ongoing study. $\mathcal{F}$ Neurosurg 1994;80:422-32.

19 Rigamonti D, Hadley MN, Drayer BP, et al. Cerebral cavernous malformations. Incidence and familial occurrence. $N$ Engl F Med 1988;319:343-7.

20 Kattapong VJ, Hart BL, Davis LE. Familial cerebral cavernous angiomas: clinical and radiologic studies. Neurology 1995;45:492-7.

21 Hayman LA, Evans RA, Ferell RE, et al. Familial cavernous angiomas: natural history and genetic study over a 5-year period. Am 7 Med Genet 1982;11:147-60.

22 Mason I, Aase JM, Orrison WW, et al. Familial cavernous angiomas of the brain in an hispanic family. Neurology 1988;38:324-6.

23 Dobyns WB, Michels VV, Groover RV, et al. Familial cavernous malformations of the central nervous system and retina. Ann Neurol 1987;21:578-83.

24 Steichen-Gersdorf E, Felber S, Fuchs W, et al. Familial cavernous angiomas of the brain: observations in a fou generation family. Eur f Pediatr 1992;151:861-3.

25 Dellemijn PLI, Vanneste JAL. Cavernous angiomatosis of the central nervous system: usefulness of screening the family. Acta Neurol Scand 1993;88:259-63.

26 Muras I, Conforti R, Scuotto A, et al. Les cavernomes cérébraux. Considérations diagnostiques. F Neuroradiol 1993; 20:34-41

27 Lechevalier B, Houtteville JP. Les cavernomes intracrâniens. Rev Neurol 1992;148:173-9.

28 Dubovsky J, Zabramski JM, Kurth J, et al. A gene responsible for cavernous malformations of the brain maps to chromosome 7q. Hum Mol Genet 1995;4:453-8.

29 Günel M, Awad I A, Anson J, Lifton RP. Mapping a gene causing cerebral cavernous malformation to 7q11.2-q21. Proc Natl Acad Sci USA 1995;92:6620-4.

30 Marchuk DA, Gallione C J, Morrison LA, et al. A locus for cerebral cavernous malformations maps to chromosome $7 \mathrm{q}$ in two families. Genomics 1995;28:311-4.

31 Johnson EW, Iyer LM, Rich SS, et al. Refined localization of the cerebral cavernous malformation gene $(\mathrm{ccm} 1)$ to a 4-cm interval of chromosome $7 \mathrm{q}$ contained in a welldefined YAC contig. Genome Res 1995;5:368-80.

32 Gil-Nagel A, Dubovsky J, Wilcox KJ, et al. Familial cerebral angioma: an autosomal dominant gene localized to a $15 \mathrm{cM}$ interval on human chromosome 7q. Ann Neurol 1996:39; interval $807-10$.

33 Hurko O, Polymeropoulos MH, Hsu F, et al. Linkage and haplotype analysis of autosomal dominant cavernous hemangiomas of the brain in four Mexican-American families. Neurol 1996;46:A172.

34 Günel M, Awad I A, Finberg K, et al. A founder mutation as a cause of cerebral cavernous malformation in Hispanic Americans. N Engl f Med 1996;334:946-51.

35 Günel M, Awad I A, Finberg K, et al. Genetic heterogeneity of inherited cerebral cavernous malformation. Neurosurgery 1996;38:1265-71

36 Weissenbach J, Gyapay G, Dib C, et al. A second generation linkage map of the human genome. Nature 1992;359:794801.

37 Tournier-Lasserve E, Joutel A, Melki J, et al. Cerebral autosomal dominant arteriopathy with subcortical infarcts and eukoencephalopathy maps to chromosome 19q12. Nat Genet 1993;3:256-9.

38 Lathrop GM, Lalouel JM, Julier C, et al. Multilocus linkage analysis in humans: detection of linkage and estimation of recombination. Am f Hum Genet 1985;37:482-98.

39 Lee KS, Spetzler RF. Spinal cord cavernous malformation in a patient with familial intracranial cavernous malformations. Neurosurgery 1990;26:877-80.

40 Dib C, Faure S, Fizames C, et al. A comprehensive genetic map of the human genome based on 5264 microsatellites. Nature 1996;380;152-4. 